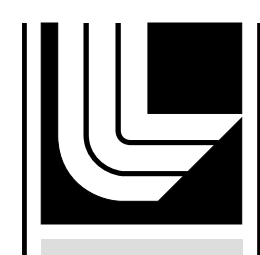

LAWRENCE LIVERMORE N A T IO N A L LABORATORY

\title{
Modeling the impact of sea-spray on particle concentrations in a coastal city
}

S. C. Pryor, R. J. Barthelmie, J. T. Schoof, F. S. Binkowski, L. Delle Monache, R. B. Stull

April 20, 2006

Science of the Total Environment 
This document was prepared as an account of work sponsored by an agency of the United States Government. Neither the United States Government nor the University of California nor any of their employees, makes any warranty, express or implied, or assumes any legal liability or responsibility for the accuracy, completeness, or usefulness of any information, apparatus, product, or process disclosed, or represents that its use would not infringe privately owned rights. Reference herein to any specific commercial product, process, or service by trade name, trademark, manufacturer, or otherwise, does not necessarily constitute or imply its endorsement, recommendation, or favoring by the United States Government or the University of California. The views and opinions of authors expressed herein do not necessarily state or reflect those of the United States Government or the University of California, and shall not be used for advertising or product endorsement purposes. 
4 Atmospheric Science Program, Department of Geography, Indiana University, Bloomington, IN 5

\section{Abstract}

19 An atmospheric chemistry-transport model is used to assess the impacts of sea-spray chemistry

20 on the particle composition in and downwind of a coastal city - Vancouver, British Columbia.

21 Reactions in/on sea-spray affect the entire particle ensemble and particularly the size distribution

22 of particle nitrate.

23 Keywords: Air pollution, sea-spray, aerosol, urban, heterogeneous chemistry 
2 The world's population is becoming increasingly urbanized with an ever greater proportion

3 located in coastal environments. Approximately half of the world's population live within $50 \mathrm{~km}$

4 of the coastline $[1,2]$ in communities that have a mean population density three times the global

5 average [3]. For this reason there is increasing interest in understanding the chemical and

6 physical interactions between marine air masses and extensively modified urban atmospheres [4,

7 5]. Improved understanding will help to inform those charged with undertaking emission-control

8 measures designed to reduce population exposure to all air pollutants [6] including fine

9 particulate matter $\left(\mathrm{PM}_{2.5}\right.$, particulate matter with a diameter of less than 2.5 microns $\left.(\mu \mathrm{m})\right)$ which

10 has been implicated in human morbidity and mortality [7].

11 Here we use the Fraser Valley (Figure 1), a region that spans the international border between

12 the Canadian province of British Columbia and the US state of Washington, as a case study of

13 coastal air pollution. Specifically we seek to investigate the role that sea-spray plays in

14 determining the PM climate of the region, and to elucidate the need for considering sea-spray in

15 policy-oriented modeling exercises. This need has become increasingly critical in the face of

16 increasing evidence that wave breaking emits significant quantities of sub-micron particles [8]

17 and hence may make a significant contribution to the mass of accumulation mode, or fine,

18 particles (diameter $\sim 0.1-1 \mu \mathrm{m}$ ) that have long atmospheric residence times (of the order of

19 days) [9] and can significantly contribute to atmospheric chemistry [10].

20 The Fraser Valley (FV) has a population of over 2 million people, the majority of whom reside in

21 the city of Vancouver and surrounding communities, and is experiencing high population growth

22 of $8 \% \mathrm{yr}^{-1}[11]$. The valley has significant anthropogenic and biogenic gaseous and particulate 
1 emissions and complex meteorology due to both topographic flows and thermally driven meso-

2 scale circulations $[12,13]$.

3 Data collected during August and September 2001 in the Pacific 2001 study [11], and previous

4 field experiments such as REVEAL (conducted during July and August 1993) [14] and

5 REVEAL II (conducted over a year-long period spanning 1994 and 1995) [15] indicate the

6 valley episodically experiences hourly average $\mathrm{PM}_{10}$ (particles below $10 \mu \mathrm{m}$ diameter)

7 concentrations above $30 \mu \mathrm{g} \mathrm{m}^{-3}, 24$-hour average $\mathrm{PM}_{2.5}$ concentrations in excess of $20 \mu \mathrm{g} \mathrm{m}^{-3}$,

8 and visual range below $10 \mathrm{~km}$. As in many other marine-influenced environments [16-18], data

9 from Pacific 2001 further indicate that in the western Fraser Valley particle-nitrate $\left(\mathrm{NO}_{3}{ }^{-}\right)$is

10 largely associated with sea-spray components (notably sodium) [19]. This implies uptake of

11 nitric acid $\left(\mathrm{HNO}_{3}\right)$ on sea-spray droplets leading to volatilization of hydrochloric acid is the

12 dominant mechanism for particle nitrate formation in the western valley. Since the maximum

13 sea-spray surface area is typically associated with particle diameters of approximately $2 \mu \mathrm{m}$ [20],

14 the resulting $\mathrm{NO}_{3}{ }^{-}$is present in both accumulation mode (particle diameter of $0.1-1 \mu \mathrm{m}$ )

15 particles and coarse mode (particle diameter of $1-10 \mu \mathrm{m}$ ) particles. In the eastern valley there is

16 evidence that particle- $\mathrm{NO}_{3}{ }^{-}$is more strongly coupled to particle- $\mathrm{NH}_{4}{ }^{+}$, implying that ammonium

17 nitrate $\left(\mathrm{NH}_{4} \mathrm{NO}_{3}\right)$ formation/condensation is the principle mechanism for particle- $\mathrm{NO}_{3}{ }^{-}$formation

18 here and that it will be largely present in the accumulation mode. This regional variability in the

19 nature and size of the resulting particle- $\mathrm{NO}_{3}{ }^{-}$may be invoked as an explanation for the

20 observation that 'white haze' dominates in the eastern valley [14] because particle size and

21 composition critically determine interactions with light that lead to visibility reduction [21].

22 Here a chemistry-transport model is applied to investigate the degree to which reactions on and

23 in sea-spray influence the size and composition of atmospheric particles in the Fraser Valley and 
1 hence the degree to which it is necessary to include these reactions in seeking to determine

2 potential emission control measures to reduce $\mathrm{PM}_{2.5}$ concentrations. The model has

3 comprehensive treatment of the sea-spray and other emissions, transport, atmospheric chemistry

4 including particle dynamics, and removal processes and is described in section 2. In section 3

5 results of simulations conducted using the model are presented and an evaluation of the model

6 performance is provided. We conclude in section 4 and articulate policy relevant insights drawn

7 from this work.

\section{MODEL DESCRIPTION}

\section{$9 \quad 2.1 \quad$ Overview of simulations}

10 Figure 1 shows the modeling domain, along with topographic data and the locations of the three

11 model receptor sites. Slocan Park is located in a residential neighborhood within the city of

12 Vancouver. Langley is located close to the international border, approximately $12 \mathrm{~km}$ from the

13 shoreline in agricultural lands. Chilliwack is located approximately $60 \mathrm{~km}$ east in the valley in a

14 mixed agricultural and urban setting. These sites were selected because they provide an overview

15 of the spatial variability in the valley and also served as measurement foci in the Pacific 2001 or

16 REVEAL field experiments. The model periods are from 2003-2004 and were selected to include

17 two winter cases (runs 1 and 2), three from the transition seasons (runs 3 and 4 from the spring,

18 and 8 from fall) and three for the summer (runs 5,6 and 7). Due to the difficulties in accurately

19 simulating precipitation and wet deposition, these 3-day periods were selected to avoid times

20 with extensive precipitation. 


\subsection{Meteorological conditions}

2 The meteorological fields used in this analysis were derived from the Mesoscale Compressible

3 Community (MC2) NWP model [22]. MC2 is a fully compressible, non-hydrostatic model using

4 semi-implicit semi-Lagrangian techniques. The model is initialized using the National Center for

5 Environmental Prediction (NCEP) North American Mesoscale (NAM) model at 108-km

6 horizontal grid spacing. One-way nesting is applied to produce model output at 36, 12, 4, and 2

$7 \mathrm{~km}$. Back trajectories (including a detailed vertical profile of meteorological parameters) from

8 each of the receptor sites are computed from the $4 \mathrm{~km}$ meteorological fields every three hours

9 and have an hourly resolution. These trajectories are then used as input to the chemical model. In

10 order not to bias the results towards inclusion of specific hours of the day, the trajectories were

11 computed to terminate at different times of the day for the three day period.

12 Back-trajectories for each of the eight 3-day simulation periods from Langley are shown in

13 Figure 2. Trajectories to Slocan Park are slightly further north than those to Langley while those

14 to Chilliwack are displaced eastward. Otherwise the trajectories are similar except that in the last

15 simulation period trajectories to Langley traverse the Olympic Peninsula while those to the other

16 two sites do not. Trajectory length exceeds 24 hours in each case and varies as a function of

17 location, since the trajectory ends when it leaves the modeling domain or after approximately 48

18 hours.

\section{$19 \quad 2.3$ Chemical model}

20 ISOPART is a trajectory model with telescoping vertical and horizontal grids. In this application,

21 the vertical column is described using 38 layers extending to the upper troposphere based on the

22 layer structure of MC2. All meteorological parameters were derived directly from MC2. 
1 Diffusion (using the first-order approximation, K-theory) and chemistry occur with a split

2 chemistry-diffusion time step.

3 The gas-phase chemical mechanism in ISOPART is based on the carbon bond mechanism [23]

4 but extended with respect to nitrogen, sulfur and VOC chemistry. The system of chemical

5 equations is solved using the highly numerically efficient Euler Backward Iterative method [24].

6 Reaction rates for photolysis reactions are corrected for sun angle (by latitude, season, and hour

7 of the day) and cloud cover derived from MC2 [9].

8 Secondary components of the ambient aerosol burden are treated as follows:

9 Inorganic chemistry leading to production of nucleating or condensable species is 10 treated as in the chemical mechanism of [25].

11 - Secondary organic aerosol (SOA) formation from monoterpenes is treated in a semi12 explicit chemical mechanism which incorporates five groups of monoterpenes; $\alpha$ -

13 pinene, $\beta$-pinene, $\Delta$-3-carene, d-limonene and ocimene [26, 27]. Gas to particle

14 partitioning is treated using the partitioning model of [28].

15 - Secondary organic aerosol formation from anthropogenic VOC is treated using

16 Fractional Aerosol Coefficients (FAC) [29]. Anthropogenic SOA is formed from the 17 following carbon bond groups according to the SOA yields shown:

- Xylene: $428 \mu \mathrm{g} \mathrm{m}^{-3} / \mathrm{ppm}$

- Toluene: $424 \mu \mathrm{g} \mathrm{m}^{-3} / \mathrm{ppm}$

20 - The flux of primary particle-sulfate, nitrate and organics are taken from the inventory and allocated to the accumulation mode. 
1 The aerosol dynamics of the resulting particle ensemble are treated within the modal framework

$2[30,31]$ with three overlapping intervals; the aitken, accumulation and coarse modes, which are

3 described as log-normal distributions:

Log normal distribution: $\mathrm{n}(\ln \mathrm{D})=\frac{\mathrm{N}}{(2 \pi)^{1 / 2} \ln \sigma_{\mathrm{g}}} \mathrm{e}^{\left[-0.5\left(\frac{\mathrm{n}\left(\mathrm{D} / \mathrm{D}_{\mathrm{g}}\right)}{\ln \sigma_{\mathrm{g}}}\right)^{2}\right]}$

$4 \quad \mathrm{~N}=$ particle number concentration

$5 \quad \mathrm{D}=$ particle diameter

$6 \quad \mathrm{D}_{\mathrm{g}}$ and $\sigma_{\mathrm{g}}=$ geometric mean diameter and standard deviation

7 The Kth moment of each mode is given by:

$\mathrm{M}_{\mathrm{k}}=\mathrm{ND}_{\mathrm{g}}^{\mathrm{k}} \mathrm{e}^{\left[\frac{\mathrm{k}^{2}}{2} \ln ^{2} \sigma_{\mathrm{g}}\right]}$

8 Where

$9 \mathrm{k}=0$ total number of aerosol particles in mode per unit volume of air

$10 \mathrm{k}=2$ particle surface area

$11 \mathrm{k}=3$ particle volume

12 Three moments are predicted and used to diagnose $\mathrm{D}_{\mathrm{g}}$ and $\sigma_{\mathrm{g}}$ as a function of time. Log-

13 normality is assumed in each mode, and each mode is assumed to have a fixed geometric

14 standard deviation.

15 ISOPART also treats heterogeneous chemistry within sea-spray droplets. The flux of sea-spray

16 into the lowest model layer is treated in 35 sections (which have a separation of $1.5 *$ volume,

$17 \mathrm{D}_{\text {pmin }}=0.01 \mu \mathrm{m}, \mathrm{D}_{\mathrm{pmax}}=10 \mu \mathrm{m}$ ) according to the ambient wind speed (at $10 \mathrm{~m}, \mathrm{U}_{10}$ ), and the

18 diameter of the spray droplets (at a nominal humidity of $80 \%$ ). The sub-micron flux is computed

19 according to [8] while the super micron flux is taken from [32]. Aerosol dynamics of the sea- 
1 spray derived droplets is confined to coagulation (intra- and inter-mode coagulation [33, 34], and

2 to facilitate tracking of sea-spray derived material and particle mass derived from homogeneous

3 reaction or condensation, coagulation with the log-normal modes is not allowed. Future work

4 will quantify the importance of this assumption and will focus on allowing interaction of the

5 non-sea-spray and sea-spray particles.

6 The emitted sea-spray is assumed to have the chemical composition of bulk sea water. Hence

7 sulfate $\left(\mathrm{SO}_{4}{ }^{2-}\right)$ in sea-spray has both a primary (direct emission) and secondary (mainly due to

8 solution of sulfur dioxide $\left.\left(\mathrm{SO}_{2}\right)\right)$ source. In the results presented here we present only excess

$9 \mathrm{SO}_{4}{ }^{2-}$ in sea-spray formed from chemical reactions and exclude the contribution from direct

10 emission as a component of the sea-spray droplets. Sea-spray is treated using a sectional

11 approach because the source functions applied do not exhibit log-normality.

12 The heterogeneous chemical module used to describe the chemistry within sea-spray droplets is

13 based on a modified version of Marine Aerosol and Gas Phase Interactions (MAGPI) module

14 [10]. The change of concentration of a species within the droplets within each section (and each

15 model grid cell) is given by:

$$
\frac{d C}{d t}=k_{T} C_{g}(t)-\frac{C(t) k_{T}}{H_{e f f(t)} R T}-r(t) C(t)
$$

16 where

$17 \mathrm{C}=$ aqueous phase concentration $\left(\mathrm{mol} \mathrm{L}_{\mathrm{are}}{ }^{-1}\right)$

$18 \quad \mathrm{C}_{\mathrm{g}}=$ gas phase concentration $\left(\mathrm{mol} \mathrm{Lair}^{-1}\right)$

$19 \mathrm{k}_{\mathrm{T}}=$ transfer coefficient $\left(\mathrm{s}^{-1}\right)$ which includes both the gas phase diffusion to the droplet (in which

20 the mean molecular speed is a function of the molecular weight and grid temperature) and the

21 mass transfer across the surface which is formulated in terms of an accommodation coefficient 
$1 \quad \mathrm{H}_{\text {eff }}=$ Henry law constant corrected for the concentrated nature of the droplets (using activity

2 coefficients) $\left(\mathrm{mol} \mathrm{atm}^{-1}\right)$

$3 \mathrm{R}=$ Universal gas constant $\left(\mathrm{atm} \mathrm{K} \mathrm{K}^{-1} \mathrm{~mol}^{-1}\right)$

$4 \mathrm{~T}=$ air temperature in the grid cell $(\mathrm{K})$

$5 \quad \mathrm{r}=$ reaction rate of $\mathrm{C}$ in the aqueous phase

6 The reactions form a set of ordinary differential equations and because the species have widely

7 differing time scales they are solved using the Hesstvedt technique [35]. Gas phase

8 concentrations are modified according to exchange with the droplets and gas phase chemistry.

9 It should be noted that the modal component of the particle dynamics conducts an equilibrium

10 calculation at each model time step (150 seconds), while the interaction with sea-spray is time

11 evolving (non-equilibrium).

12 Dry deposition of gases is treated using the resistance analogue [25], while dry deposition of

13 particles is computed using a size and chemically resolved model [20].

14 Modeled aerosol and gaseous concentrations are used to calculate the components of light

15 extinction ( $\left.b_{\text {ext }}\right)$ on line $\left(b_{\mathrm{sp}}=\right.$ particle light scattering, $b_{\mathrm{ap}}=$ particle light absorption, $\mathrm{b}_{\mathrm{sg}}=$ gas

16 light scattering and $\mathrm{b}_{\mathrm{ag}}=$ gas light absorption) and visual range $\left(\mathrm{VR} \sim 3.91 / \mathrm{b}_{\text {ext }}\right)$ according to the

17 IMPROVE protocols $[36,37]$. At this juncture it is important to note that previous studies have

18 indicated that $b_{\mathrm{sp}}$ dominates light extinction and hence visibility impairment in the valley [14]

19 and that the calculation of $b_{\mathrm{sp}}$ using the IMPROVE protocols is critically dependent on the

20 simulated relative humidity $(\mathrm{RH})$ from $\mathrm{MC} 2$ :

$$
\begin{aligned}
& \mathrm{b}_{\mathrm{sp}}=(0.003) \mathrm{f}(\mathrm{RH})[\text { sulfate }]+(0.003) \mathrm{f}(\mathrm{RH})[\text { nitrate }]+(0.003)[\mathrm{OCM} / 2] \\
& +(0.003) \mathrm{f}(\mathrm{RH})[\mathrm{OCM} / 2]+0.001[\text { soil }]+0.0006[\mathrm{CM}] \\
& \mathrm{b}_{\mathrm{ap}}=0.1 * 10^{-3}[\mathrm{EC}]
\end{aligned}
$$




$$
\begin{aligned}
& \mathrm{b}_{\mathrm{sg}}=11.4 * 10^{-6} \\
& \mathrm{~b}_{\mathrm{ag}}=0.33 * 10^{-3}\left[\mathrm{NO}_{2}\right]
\end{aligned}
$$

1 Concentrations are in $\mu \mathrm{g} \mathrm{m}^{-3}$ except for $\mathrm{NO}_{2}$ which has units of ppb, and the extinction

2 components are in $\mathrm{m}^{-1}$.

3 Where:

$$
f(R H)=0.33713+0.58601\left(\frac{100}{100-R H}\right)+0.09164\left(\frac{100}{100-R H}\right)^{2}
$$

4 And $\mathrm{f}(\mathrm{RH})$ is normalized to give a value of 1 at $\mathrm{RH}=30 \%$.

\section{$5 \quad 2.4 \quad$ Emissions}

6 Emissions were prepared using the Sparse Matrix Operator Kernel Emission (SMOKE) system

7 [38] which supports area, mobile, and point source emission processing. SMOKE-Biogenic

8 Emission Inventory System version 2 (BEIS2) is used to estimate biogenic emissions [39]. The

9 emission inventory for the major metropolitan areas in the Lower Fraser Valley (LFV) was

10 derived for a base year of 2000, while for the rest of the domain it is for 1996 grown to 2000.

11 The meteorologically-dependent components of the SMOKE emissions modeling system use as

12 input the meteorological fields produce by MC2. Emissions are allocated to 17 heights between

$13 \quad 13$ and $11188 \mathrm{~m}$.

\section{$14 \quad 2.5 \quad$ Initial conditions}

15 The chemical concentrations used to initialize the ISOPART model are based on ambient

16 measurements or previous modeling exercises, except those for Volatile Organic Compounds

17 (VOC) were taken from [40] and redistributed into Carbon Bond groups [23] as shown in Table 
1 1. Initial concentrations were assumed to be invariant with time and the location of the trajectory

2 start point.

3 A key uncertainty in the modeling is the initialization of the vertical profile of sea-spray. Very

4 few observations of sea-spray profiles have been conducted [41] and it is known that it takes

5 over 24-hours to establish an equilibrium vertical profile even assuming a constant wind speed

6 [42]. Air masses that influence the Fraser Valley typically originate over the Pacific Ocean.

7 Based on previous research [42], if the trajectory begins over the ocean, sea-spray is emitted,

8 dispersed and deposited for 24 hours, using the 10-m wind speed from MC2 for the first

9 trajectory hour to determine the emissions and the vertical profile of meteorological parameters

10 again from MC2 to dictate the vertical dispersion and deposition. If the trajectory begins over a

11 land surface, sea-spray is emitted, dispersed and deposited for 24 hours as described above. The

12 profile is then transported for 12 hours over a land-surface during which time diffusion and

13 deposition occur again, according to the meteorological conditions in the first hour of the

14 trajectory.

\section{$15 \quad 2.6 \quad$ Model scenarios}

16 We conducted three sets of simulations:

17 - Experiment A: A set of simulations where ISOPART was applied excluding sea-spray

18 emission and chemistry. This set of simulations mimics the treatment of particle dynamics

19 common to many atmospheric chemistry models applied for emission-scenario testing.

20 - Experiment B: A set of simulations where the full ISOPART model was applied to produce a

21 set of simulations that includes sea-spray emissions and chemistry. In these simulations the

22 vertical profiles of sea-spray were initialized based on the $10-\mathrm{m}$ wind speed from the first

23 hour of the trajectory. 
1 - Experiment C: A set of simulations where ISOPART was applied as in B except the sea-

2 spray initial profile was determined using a constant wind speed of $7 \mathrm{~m} \mathrm{~s}^{-1}$ at $10-\mathrm{m}$ height.

3 This set of simulations was conducted to assess the impact of uncertainties in the initial sea-

$4 \quad$ spray profile on the model results.

\section{RESULTS}

\section{$6 \quad 3.1 \quad$ Experiment A}

7 Figure 3 synthesizes the concentrations of the major inorganic components of $\mathrm{PM}_{2.5}$ in the eight

8 simulation periods at the three receptor sites while Table 2 provides the mean total $\mathrm{PM}_{2.5}$ from

9 the inorganic ions, organic and elemental carbon. At all three receptors the average $\mathrm{PM}_{2.5}$

10 concentration in all eight simulation periods varies between 5 and $16 \mu \mathrm{g} \mathrm{m}^{-3}$. An interim Canada

11 Wide Standard for $\mathrm{PM}_{2.5}$ of $30 \mu \mathrm{g} \mathrm{m}^{-3}$ over a 24 hour averaging time, to be achieved by the year

12 2010, was endorsed in 2000 by the Canadian Council of Ministers of the Environment June 5-6,

132000 , Quebec City. Hence none of the modeled daily average $\mathrm{PM}_{2.5}$ concentrations at any of the

14 sites exceeded this level. Also at each of the sites mean modeled ion balance for the triad $\mathrm{NH}_{4}{ }^{+}$-

$15 \mathrm{NO}_{3}{ }^{-}-\mathrm{SO}_{4}{ }^{2-}$ in the modal aerosol dynamics is $1 \pm 0.09$ for all cases indicating sufficient

16 ammonia $\left(\mathrm{NH}_{3}\right)$ at each site to fully neutralize the anion species $\left(\mathrm{NO}_{3}{ }^{-}\right.$and $\left.\mathrm{SO}_{4}{ }^{2-}\right)$.

17 At all sites $\mathrm{SO}_{4}{ }^{2-}$ is the inorganic ion that contributes most to $\mathrm{PM}_{2.5}$ mass. However, organic

18 carbon (OC) also makes a substantial contribution at all sites. OC concentrations are highest in

19 spring and summer simulations at Slocan Park and in the summer at Langley and Chilliwack,

20 likely due in part to the higher primary OC emissions at Slocan Park. At Slocan Park all

21 inorganic ions are highest in the two spring cases, while at both Chilliwack and Langley $\mathrm{SO}_{4}{ }^{2-}$ is

22 consistent throughout all the cases, and the nitrogen ions exhibit variability more strongly

23 associated with the trajectory path than season. 
1 In accord with observations in the valley which indicate substantial spatial variability (see

2 references cited above), the model simulates spatial variability of PM concentrations, speciation

3 and the period with highest PM concentrations (run 3 at Slocan Park, run 1 at Langley and run 2

4 at Chilliwack). However, in contrast to measurements conducted during REVEAL the model

5 indicates higher average $\mathrm{PM}_{2.5}$ in Vancouver (at Slocan Park) than Langley and Chilliwack,

6 possibly in part due to bias in the meteorological conditions during the simulations (e.g.

7 exclusion of precipitation events, or the dominance of meteorological conditions which favor

8 down-valley flow (Figure 2)). The model results indicate generally more particle- $\mathrm{NO}_{3}{ }^{-}$at Slocan

9 Park than at Langley and Chilliwack, which may also be partly due to down-valley flows in the

10 model simulations and the generally low modeled wind speeds leading to processing of oxides of

11 nitrogen to $\mathrm{HNO}_{3}$ close to their urban source.

\section{$12 \quad 3.2 \quad$ Experiments $B$ and $C$}

13 As shown in Figure 3, the first set of simulations conducted including sea-spray emissions and

14 reactions (i.e. experiment B) indicate particle- $\mathrm{NO}_{3}{ }^{-}$concentrations are dominated by $\mathrm{NH}_{4} \mathrm{NO}_{3}$

15 rather than the products of reactions on/in sea-spray. At Slocan Park in all cases there is twice as

16 much particle- $\mathrm{NO}_{3}{ }^{-}$as $\mathrm{NH}_{4} \mathrm{NO}_{3}$ than $\mathrm{NO}_{3}{ }^{-}$in sea-spray, at Chilliwack this is also the case for the

17 majority of the simulations, while at Langley the contributions to particle- $\mathrm{NO}_{3}^{-}$from $\mathrm{NH}_{4} \mathrm{NO}_{3}$

18 and aged sea-spray are approximately comparable. This is likely due to the following:

19 i. In selecting the case studies to avoid precipitation cases we have biased the case studies

20 towards down-valley flows and hence advection of air from the central valley towards the

21 city (see Figure 2).

22 ii. The high RH simulated by MC2 which will tend to facilitate the formation of, and 23 stabilization of, $\mathrm{NH}_{4} \mathrm{NO}_{3}$. 
1 However, as discussed below, the partitioning of particle- $\mathrm{NO}_{3}{ }^{-}$is also critically dependent on the

2 amount of sea-spray present in the initialization profile.

3 Figure 3 shows a non-linear response to the presence of sea-spray and to the wind speed used to

4 condition the initial profile. In all but one of the simulation runs, inclusion of sea-spray reactions

5 increases total particle- $\mathrm{NO}_{3}{ }^{-}$, but slightly decreases particle sulfate $\left(\mathrm{SO}_{4}{ }^{2-}\right)$. This is because the

6 sea-spray ensemble has a higher deposition velocity than the modal particles, but the sea-spray

7 particles which dominant surface area (and hence uptake of soluble gases) in the model typically

8 have a lower deposition velocity than either $\mathrm{HNO}_{3}$ or $\mathrm{NH}_{3}$. The inclusion of sea-spray reactions

9 not only affects the total particle concentrations but also profoundly influences the size

10 distribution. For example, the peak in particle- $\mathrm{NO}_{3}{ }^{-}$occurs at a diameter below $0.5 \mu \mathrm{m}$, while

11 particle- $\mathrm{NO}_{3}{ }^{-}$in sea-spray exhibits highest concentrations in particles of approximately $1-2 \mu \mathrm{m}$

12 diameter. This redistribution of nitrate between $\mathrm{NH}_{4} \mathrm{NO}_{3}$ and $\mathrm{NaNO}_{3}$ and redistribution by size

13 has profound implications for the particle light scattering and hence visibility impairment [21]

14 which is not captured by the IMPROVE protocols (equations 4-8) which implicitly assume all

$15 \mathrm{PM}_{2.5}$ nitrate is present as $\mathrm{NH}_{4} \mathrm{NO}_{3}$ and that the particle diameter has no effect so long as it

16 remains below $2.5 \mu \mathrm{m}$. For this reason, while inclusion of sea-spray reactions tends to lead to

17 higher visual range (Figure 4), the effect is relatively modest.

18 From the simulations conducted under experiment B it is difficult to assess the seasonality of the

19 partitioning of particle- $\mathrm{NO}_{3}{ }^{-}$because of the strong dependence on wind speed of the sea-spray

20 emissions. When the initialization wind speed is held constant, as expected, sea-spray related

21 particle- $\mathrm{NO}_{3}{ }^{-}$is highest in the winter, when $\mathrm{NH}_{3}$ emissions, and hence availability, are at a

22 minimum. In accord with expectations, modeled $\mathrm{NH}_{4} \mathrm{NO}_{3}$ concentrations are typically higher at 
1 Chilliwack than Langley, but even at Chilliwack, there is evidence for a substantial contribution

2 from sea-spray related nitrate.

3 As shown in Figure 3, the partitioning of particle- $\mathrm{NO}_{3}{ }^{-}$between $\mathrm{NH}_{4} \mathrm{NO}_{3}$ and $\mathrm{NaNO}_{3}$ is very

4 sensitive to the wind speed used to initialize the sea-spray concentration profile in the model. In

5 simulations conducted with a fixed wind speed of $7 \mathrm{~m} \mathrm{~s}^{-1}$ for the initialization of the sea-spray at

6 all sites and simulation periods, particle- $\mathrm{NO}_{3}{ }^{-}$was predominantly associated with sea-spray.

\section{$7 \quad 3.3 \quad$ Evaluation of experiment B relative to ambient measurements}

8 Although the primary focus of the paper is not to evaluate or validate the ISOPART model,

9 assuming experiment B most closely represents ambient conditions in the valley, here we

10 synthesize a comparison of the modeled concentrations with ambient measurements. In Figure 5

11 mean concentrations of key particle precursor species and oxidants $\left(\mathrm{NH}_{3}, \mathrm{SO}_{2}, \mathrm{HNO}_{3}\right.$ and ozone

$\left.12\left(\mathrm{O}_{3}\right)\right)$ are given for each base case model run over each of the eight 3-day periods. For

13 comparison annual mean hourly data for 2003 from the closest monitoring sites from the Greater

14 Vancouver and Fraser Valley Regional District air-quality monitoring networks are also given

15 [43]. The monitoring sites used are: Vancouver (T1) just east of Slocan Park, Langley (T27) just

16 north of Langley and Chilliwack (T12) within the Chilliwack grid cell. It should be noted that the

17 observations are displaced either in space or time relative to the model, and also that the

18 observations are point measurements while the model is a volume average over a grid cell of $5 \mathrm{x}$

$195 \mathrm{~km} x$ the layer thickness. Nevertheless, both modeled and measured $\mathrm{SO}_{2}$ concentrations are in

20 the low ppb range. Model simulations for Slocan Park and Chilliwack exhibit a one hour

21 maximum $\mathrm{O}_{3}$ concentration over the three day simulation periods of 24-61 ppb over the eight

22 cases. At Langley the maximum hourly average concentration ranges from 26 to $81 \mathrm{ppb}$. Again,

23 these values are in broad accord with the observed data which indicate annual maximum $\mathrm{O}_{3}$ 
1 concentrations of $54 \mathrm{ppb}$ at $\mathrm{T} 1,80 \mathrm{ppb}$ at $\mathrm{T} 27$ and $83 \mathrm{ppb}$ at T12. Ammonia is not routinely

2 measured in the Fraser Valley but during the Pacific 2001 field campaign mean concentrations of

$3 \mathrm{NH}_{3}$ were $0.2 \mathrm{ppb}$ at Slocan Park and $0.4 \mathrm{ppb}$ at Langley [19] again in agreement with the

4 modeled concentrations. Four hour average $\mathrm{HNO}_{3}$ concentrations during Pacific 2001 varied

5 between 0.1 and $3.0 \mathrm{ppb}$ [44], with a mean of approximately $0.5 \mathrm{ppb}$ which is also in good

6 accord with the modeled values.

7 Mean 12 hour $\mathrm{PM}_{2.5}$ concentration at Slocan Park measured gravimetrically during Pacific 2001

8 was $8.5 \mu \mathrm{g} \mathrm{m}^{-3}[45]$ while the model simulations of the summer cases have an average of $8.8 \mu \mathrm{g}$

$9 \mathrm{~m}^{-3}$ excluding the contribution from water (Table 2). The mean observed concentrations of

10 organic carbon (OC) and elemental carbon (EC) during Pacific 2001 at Slocan Park were $3.5 \mu \mathrm{g}$ -

$11 \mathrm{C} \mathrm{m}^{-3}$ and $0.32 \mu \mathrm{g}-\mathrm{C} \mathrm{m}^{-3}$ [45], while the model simulations for summer indicate mean

12 concentrations of $3.7 \mu \mathrm{g}-\mathrm{C} \mathrm{m}^{-3}$ and $0.5 \mu \mathrm{g}-\mathrm{C} \mathrm{m}^{-3}$, respectively. Mean concentrations of organics,

$13 \mathrm{SO}_{4}{ }^{2-}, \mathrm{NH}_{4}{ }^{+}$and $\mathrm{NO}_{3}{ }^{-}$(with diameters $\sim 60 \mathrm{~nm}$ to $0.6 \mu \mathrm{m}$ ) observed at Slocan Park during

14 Pacific 2001 using the Aerodyne Aerosol Mass Spectrometer (AMS) were: 4.6, 0.9, 0.5 and 0.6

$15 \mu \mathrm{g} \mathrm{m}^{-3}$ [46] while the model concentrations in this size range are $3.4,1.3,0.6$ and $0.5 \mu \mathrm{g} \mathrm{m}^{-3}$.

16 The mean modeled $\mathrm{PM}_{2.5}$ concentration at Langley for the summer cases has an average of 7.7

$17 \mu \mathrm{g} \mathrm{m}^{-3}$ excluding the contribution from water. As in the measurements taken with a Micro-

18 Orifice Uniform Deposit Impactor (MOUDI-110) a significant fraction of the particle- $\mathrm{NO}_{3}{ }^{-}$is in

19 super-micron particles [19]. The base case simulations underestimate summertime particle- $\mathrm{NO}_{3}{ }^{-}$

20 as measured using the MOUDI (average of the model results $\sim 6 \mathrm{nmol} \mathrm{m}^{-3}$ ) but the mean

21 modeled particle- $\mathrm{NO}_{3}{ }^{-}$in the summer case simulations with the fixed initialization wind speed

22 (experiment $\mathrm{C}$ ) is $13 \mathrm{nmol} \mathrm{m}^{-3}$ which agrees very well with the MOUDI measurements from

23 Pacific 2001 when the mean particle- $\mathrm{NO}_{3}{ }^{-}$was $12 \mathrm{nmol} \mathrm{m}^{-3}$. It is worthy of note that the mean 
1 particle- $\mathrm{NO}_{3}{ }^{-}$measured using the AMS at Langley was $0.29 \mu \mathrm{g} \mathrm{m}^{-3}$ (approximately $5 \mathrm{nmol} \mathrm{m}^{-3}$ ),

2 while the modeled concentration in the size range to which the AMS is most sensitive is 3-4

$3 \mathrm{nmol} \mathrm{m}^{-3}$. The model overestimates the amount of $\mathrm{NH}_{4}{ }^{+}$and $\mathrm{SO}_{4}{ }^{2-}$ relative to the MOUDI

4 measurements by almost a factor of two which may be due to high RH simulated by MC2 which

5 would lead to excess formation (or stability) of ammonium sulfate $\left(\left(\mathrm{NH}_{4}\right)_{2} \mathrm{SO}_{4}\right)$ and ammonium

6 bi-sulfate $\left(\mathrm{NH}_{4} \mathrm{HSO}_{4}\right)$.

7 The mean modeled $\mathrm{PM}_{2.5}$ concentration at Chilliwack for the summer cases has an average of 7.2

$8 \mu \mathrm{g} \mathrm{m}^{-3}$ excluding the contribution from water, while the mean 24 hour average $\mathrm{PM}_{2.5}$ at

9 Chilliwack during REVEAL was $8.9 \mu \mathrm{g} \mathrm{m}^{-3}$. The annual mean $\mathrm{PM}_{2.5}$ at Chilliwack during 2003

10 measured using a Tapered Elemental Oscillating Microbalance (TEOM) as part of the

11 monitoring network is $5 \mu \mathrm{g} \mathrm{m}^{-3}$ while the mean model concentration is $7.4 \mu \mathrm{g} \mathrm{m}^{-3}$. The

12 difference between these two values may indicate a bias in the model simulations towards

13 periods without precipitation. Particle-OC during the summer simulations was $3 \mu \mathrm{g} \mathrm{m}^{-3}$ relative

14 to a mean during REVEAL of $3.5 \mu \mathrm{g} \mathrm{m}^{-3}$. Mean modeled particle- $\mathrm{SO}_{4}{ }^{2-}$ in the summer case

15 simulations is $2.7 \mu \mathrm{g} \mathrm{m}^{-3}$ which is in very good agreement with data from REVEAL, but mean

16 particle- $\mathrm{NO}_{3}{ }^{-}$is underestimated by the model (average of the summer simulations is less than 0.5

$17 \mu \mathrm{g} \mathrm{m}^{-3}$ ) relative to data from REVEAL. Annual mean particle- $\mathrm{NH}_{4}{ }^{+}$from filter packs deployed at

18 Clearbrook (west of Chilliwack) was $1.7 \mu \mathrm{g} \mathrm{m}^{-3}$ [19], while the mean modeled total particle-

$19 \mathrm{NH}_{4}^{+}$from the modeling for Chilliwack is $1.1 \mu \mathrm{g} \mathrm{m}^{-3}$. The offset between these concentrations

20 may be due to the spatial separation of the sites and hence local influences, or to underestimation

21 of reduced-N availability to due errors in the $\mathrm{NH}_{3}$ emission inventory, or to underestimation of

22 particle nitrate in the model simulations. Nevertheless the fraction of total particle- $\mathrm{NO}_{3}{ }^{-}$present

23 as $\mathrm{NH}_{4} \mathrm{NO}_{3}$ is higher at Chilliwack than Slocan Park or Langley. This may reasonably be 
1 attributed to; the production of $\mathrm{HNO}_{3}$ during advection of air from the major sources of oxides of

2 nitrogen (NOx) in the west of the valley, deposition of sea-spray again with increasing distance

3 from the source region and greater availability of $\mathrm{NH}_{3}$ in the more agriculturally dominated

4 eastern valley [47]. In this context it is worthy of note that total reduced nitrogen at Chilliwack

5 is, on average, twice as high at Chilliwack than at Langley.

6 The mean $b_{\text {ext }}$ as simulated by ISOPART has an average of $0.106 \mathrm{~km}^{-1}$ giving a mean VR of

7 approximately $37 \mathrm{~km}$ for Slocan Park and Langley (Figure 4). This is biased low relative to

8 observations at Pitt Meadows (slightly east of Slocan Park) during REVEAL (mean hourly $b_{\mathrm{sp}}$ at

9 Pitt Meadows was $\left.0.057 \mathrm{~km}^{-1}\right)$. We speculate this is due, in part, to very high simulated RH by

10 the MC2 model. Mean hourly $b_{\mathrm{sp}}$ at Clearbrook (slightly further inland than Langley) during

11 REVEAL exceeded $0.080 \mathrm{~km}^{-1}$, and the annual mean VR at Clearbrook during REVEAL II was

$1230 \mathrm{~km}$ [15]. The mean $b_{\mathrm{ext}}$ as simulated by ISOPART for Chilliwack is $0.078 \mathrm{~km}^{-1}$ giving a mean

13 VR of approximately $50 \mathrm{~km}$, which is higher than estimates from REVEAL (37 km) or REVEAL

14 II $(36 \mathrm{~km})$ [15] possibly due to the underestimation of particle- $\mathrm{NO}_{3}{ }^{-}$. In synthesis, modeling

15 visibility is even more challenging than modeling the particle ensemble, and the results from

16 these analyses do not fully represent the observed west-east gradient in $b_{\text {ext }}$ and visual range

17 within the Fraser Valley due in part to the sensitivity of modeled $b_{\text {ext }}$ to RH and to the

18 simplifications made in the IMPROVE protocols with regards to the particle size distribution.

\section{SUMMARY}

20 Urban air quality, and particularly airborne particles, is a major concern in terms of human health

21 impacts. Sea-spray is known to be a major component of the particle ensemble at coastal sites yet

22 relatively few air quality models include the interaction of gases with sea-spray and the fate of

23 the particles produced. Sea-spray is not an inert addition to the particle ensemble because 
1 heterogeneous chemistry in/on sea-spray droplets changes the droplets composition and the

2 particle size distribution, which impacts deposition and the ion balance in different particle size

3 fractions.

4 It is shown that the ISOPART model is capable of simulating gas and particle concentrations in

5 the coastal metropolis of Vancouver and the surrounding valley. It is also demonstrated that to

6 accurately simulate ambient concentrations of particles and reactive/soluble gases in a coastal

7 valley it is absolutely critical to include heterogeneous chemistry in/on sea-spray. Partitioning of

8 total particle- $\mathrm{NO}_{3}{ }^{-}$between sea-spray and $\mathrm{NH}_{4} \mathrm{NO}_{3}$ is highly sensitive to the amount of sea-spray

9 present, and hence the initial vertical profile, sea-spray source functions [48] and the wind speed.

10 When a fixed wind speed is used to initialize the sea-spray vertical profiles, as expected, the sea-

11 spray concentration decays with distance inland, but the particle- $\mathrm{NO}_{3}{ }^{-}$concentration decays more

12 slowly because it is also a function of the uptake rate for $\mathrm{HNO}_{3}$.

13 The simulation results imply model analyses of air quality in coastal cities conducted without

14 inclusion of sea-spray interactions may yield highly mis-leading results in terms of emission

15 sensitivities of the PM size distribution. The sensitivity of the model results to the initial sea-

16 spray profile further suggests there would be great benefit in better definition of the vertical

17 profile of size resolved sea-spray for use in such model studies.

\section{ACKNOWLEDGEMENTS}

19 Ole Hertel of NERI kindly provided original code on which the chemical mechanism of

20 ISOPART is based and David Erickson of NASA generously provided the MAGPI code. This

21 research was funded in part by Environment Canada and the Clean Air Research Fund. The

22 initial development of ISOPART was funded by Environment Canada and the National Science

23 Foundation (ATM 971755), and continuing funding from NSF (ATM 0334321) is also gratefully 
1 acknowledged. Additional funding came from the Canadian Natural Sciences and Engineering

2 Research Council and the British Columbia Ministry of Environment. For the MC2 and CMAQ

3 runs, Geophysical Disaster Computational Fluid Dynamics Centre computers were used, funded

4 by the Canadian Foundation for Innovation, the British Columbia Knowledge Development

5 Fund, and the University of British Columbia. We thank Dr. Xingxiu Deng and Mr. Yan Shen

6 for running the MC2 model at UBC, and Dr. Henryk Modzelewski and Mr. George Hicks II for

7 managing the data.

\section{REFERENCE LIST}

9 1. C.N. Hodges, T. Thompson, J. Riley and E. Glenn, Ambio 22 (1993) 483-490.

10 2. B. von Bodungen and R.K. Turner, Science and Integrated Coastal Management.

11 Dahlem University Press, Berlin Germany, 2001.

12 3. C. Small and R.J. Nicholls, Journal of Coastal Research 19 (2003) 584-599.

13 4. E.M. Knipping and D. Dabdub, Environmental Science and Technology 37 (2003) 27514284.

15 5. C. Pilinis, K.P. Capaldo, A. Nenes and S.N. Pandis, Aerosol Science and Technology 32

16 (2000) 482-502.

17 6. M.J. Molina and L.T. Molina, Journal of the Air \& Waste Management Association 54 18 (2004) 644-680.

$197 . \quad$ M. Lippmann et al., Environmental Health Perspectives 111 (2003) 1074-1092.

20 8. Eartensson, E.D. Nilsson, G. de Leeuw, L. Cohen and H.C. Hansson, Journal of

21 Geophysical Research 108 (2003) doi: 10.1029/2002JD002263.

22 9. J. Seinfeld and S. Pandis, Atmospheric chemistry and physics: from air pollution to

23 climate change. Wiley-Interscience, 1998.

24 10. D.J. Erickson, C. Seuzaret, W.C. Keene and S.L. Gong, Journal of Geophysical Research

$25 \quad \mathbf{1 0 4}(1999) 8347-8372$.

26 11. S.M. Li, Atmospheric Environment 38 (2004) 5719-5731.

27 12. B.J. Snyder and K.B. Strawbridge, Atmospheric Environment 38 (2004) 5733-5743.

28 13. I.G. McKendry et al., Atmospheric Environment 31 (1997) 2135-2146.

29 14. S.C. Pryor, R. Simpson, L. Guise-Bagley, R. Hoff and S. Sakiyama, Journal of the Air

$30 \quad$ and Waste Management Association. 41 (1997) 147-156.

31 15. S.C. Pryor and R.J. Barthelmie, Science of the Total Environment 257 (2000) 95-110.

32 16. K. Hara, K. Osada, M. Hayashi, K. Matsunaga, T. Shibata, Y. Iwasaka and K. Furuya,

33 Journal of Geophysical Research 104 (1999) 23671-23679.

34 17. X. Yao, M. Fang and C.K. Chan, Atmospheric Environment 37 (2003) 743-751.

35 18. D. Zhang, G. Shi, Y. Iwasaka and M. Hu, Atmospheric Environment 34 (2000) 2669362679. 
19. S.C. Pryor, K. Anlauf, H. Boudries, K. Hayden, C. Schiller and A. Wiebe, Atmospheric

20. $\quad$ S.C. Pryor and L.L. Sørensen, Journal of Applied Meteorology 39 (2000) 725-731.

21. H. Horvath, Effects on visibility, weather and climate. Chapter 13 . in: Atmospheric Acidity, eds. M. Radojevic and R. Harrison, Elsevier Applied Science, 1992, pp. 587.

22. R. Benoit, M. Desgagne, P. Pellerin, S. Pellerin, Y. Chartier and S. Desjardins, Monthly Weather Review 125 (1997) 2382-2415.

23. M.W. Gery, G.Z. Whitten, J.P. Killus and M.C. Dodge, Journal of Geophysical Research 94 (1989) 12925-12956.

24. O. Hertel, R. Berkowicz, J. Christensen and O. Hov, Atmospheric Environment 27 (1993) 2591-2611.

25. O. Hertel, J. Christensen, E.H. Runge, W.A.H. Asman, R. Berkowicz and M.F. Hovmand, Atmospheric Environment 29 (1995) 1267-1290.

26. R.J. Barthelmie and S.C. Pryor, Journal of Geophysical Research 104 (1999) 2356723571.

27. R.J. Barthelmie and S.C. Pryor, Journal of Geophysical Research In review (2002).

28. J.R. Odum, T. Hoffman, F. Bowman, D. Collins, R.C. Flagan and J.H. Seinfeld, Environmental Science and Technology 30 (1996) 2580-2585.

29. S.N. Pandis, R.A. Harley, G.R. Cass and J.H. Seinfeld, Atmospheric Environment 26A (1992) 2269-2282.

30. F.S. Binkowski and U. Shankar, Journal of Geophysical Research 100 (1995) 2619126209.

31. F.S. Binkowski and S.J. Roselle, Journal of Geophysical Research 108 (2003) doi:10.1029/2001JD001409.

32. E.C. Monahan, D.E. Spiel and K.L. Davidson, A model of marine aerosol generation via whitecaps and wave disruption, in: Oceanic Whitecaps, eds. E.C. Monahan and G. Mac Niocaill, D. Reidel Publishing Company, 1986, pp. 167-174.

33. M.Z. Jacobson, R.P. Turco, E. Jensen and O.B. Toon, Atmospheric Environment 28 (1994) 1327-1338.

34. M.Z. Jacobson, Journal of Geophysical Research 107 (2002) 10.1029/2001JD002044,2002.

35. E. Hesstvedt, O. Hov and I.S.A. Isaksen, International Journal of Chemical Kinetics $\mathbf{1 0}$ (1978) 971-994.

36. W.C. Malm, K.A. Gebhart, J. Molenar, T. Cahill, R. Eldred and D. Huffman, Atmospheric Environment 28 (1994) 347-360.

37. W.C. Malm, J.F. Sisler, D. Huffman, R.A. Eldred and T. Cahill, Journal of Geophysical Research 99 (1994) 1347-1370.

38. C.J. Coats Jr. High-performance algorithms in the Sparse Matrix Operator Kernel Emissions (SMOKE) modeling system. in 9th AMS Joint Conference on Applications of Air Pollution Meteorology with A\&WMA. 1996. Atlanta, GA: AMS.

39. J. Vukovich. Development of biogenic emissions for the 1995 summer season. in Emission Inventories Conference, Air \&Waste Management Association Conference. 1998. New Orleans, LA: A\&WMA.

40. W.R. Stockwell, F. Kirchner and M. Kuhn, Journal of Geophysical Research 102 (1997) 25847-25879. 
41. Y. Shinozuka, A.D. Clarke, S.G. Howell, V.N. Kapustin and B.J. Huebert, Journal of Geophysical Research 109 (2004) doi:10.1029/2004JD004975.

42. W.A. Hoppel, G.M. Frick and J.W. Fitzgerald, Journal of Geophysical Research 107 (2002) 10.1029/2001JD002014,2002.

43. F. GVRD, Lower Fraser Valley Ambient Air Quality Report 2003. 2004: Vancouver, B.C. p. 42 pp.

44. K. Hayden, K. Anlauf, S.M. Li, A. MacDonald, J. Bottenheim, J. Brook and A. Wiebe, Atmospheric Environment 38 (2004) 5811-5823.

45. X. Fan, J. Brook and S.A. Mabury, Atmospheric Environment 38 (2004) 5801-5810.

46. H. Boudries et al., Atmospheric Environment 38 (2004) 5759-5774.

47. R.J. Barthelmie and S.C. Pryor, Atmospheric Environment 32 (1998) 345-352.

48. W. Guelle, M. Schulz, Y. Balkanski and F. Dentener, Journal of Geophysical Research 106 (2001) 27509-27524.

This work was performed under the auspices of the U.S. Department of Energy by University of California, Lawrence Livermore National Laboratory under Contract W-7405-Eng-48. 
1 Table 1. Model initialization concentrations. *Converted to CBM IV groups from concentrations 2 in [40]. Note particle- $\mathrm{NH}_{4}{ }^{+}$is defined based on the particle- $\mathrm{SO}_{4}{ }^{2-}$ and $\mathrm{NO}_{3}{ }^{-}$which are 3 assumed to be present as $\left(\mathrm{NH}_{4}\right)_{2} \mathrm{SO}_{4}$ and $\mathrm{NH}_{4} \mathrm{NO}_{3}$.

\begin{tabular}{|c|c|c|}
\hline \multicolumn{2}{|r|}{ Gases } & Concentration in $\mathrm{ppb}$ \\
\hline \multicolumn{2}{|r|}{$\mathrm{NO} / \mathrm{NO}_{2}$} & $0.5 / 1.0$ \\
\hline \multicolumn{2}{|r|}{$\mathrm{O}_{3}$} & 30. \\
\hline \multicolumn{2}{|r|}{$\mathrm{CO}$} & 200. \\
\hline \multicolumn{2}{|r|}{$\mathrm{SO}_{2}$} & 1. \\
\hline \multicolumn{2}{|r|}{$\mathrm{NH}_{3}$} & 1. \\
\hline \multicolumn{2}{|r|}{$\mathrm{HNO}_{3}$} & 0.1 \\
\hline \multicolumn{2}{|r|}{$\alpha$-pinene } & 0.7 \\
\hline \multirow{8}{*}{ 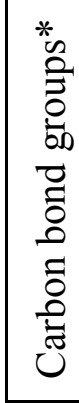 } & OLE & 0.3 \\
\hline & PAR & 29.1 \\
\hline & TOL & 1.9 \\
\hline & XYL & 0.3 \\
\hline & FORM & 0.1 \\
\hline & ALD & 0.1 \\
\hline & ETH & 0.7 \\
\hline & ISOP & 0.7 \\
\hline \multicolumn{2}{|r|}{ Aerosol } & Concentration in $\mu \mathrm{g} \mathrm{m}^{-3}$ \\
\hline \multicolumn{2}{|r|}{ Particle- $\mathrm{SO}_{4}{ }^{2-}$} & 0.6 \\
\hline \multicolumn{2}{|r|}{ Particle- $\mathrm{NO}_{3}{ }^{-}$} & 0.5 \\
\hline \multicolumn{2}{|r|}{ Particle-OC } & 0.1 \\
\hline
\end{tabular}


1 Table 2. Total $\mathrm{PM}_{2.5}\left(\mu \mathrm{g} \mathrm{m}^{-3}\right)$ (sulfate, nitrate, ammonium, sodium, organics and elemental carbon) but 2 excluding the mass attributable to associated water at the three receptors for Experiment A, B and C.

\begin{tabular}{|c|c|c|c|c|c|c|c|c|c|}
\hline & \multicolumn{3}{|c|}{ Slocan Park } & \multicolumn{3}{c|}{ Langley } & \multicolumn{3}{c|}{ Chilliwack } \\
\hline $\begin{array}{c}\text { Experiment/ } \\
\text { Simulation \# }\end{array}$ & $\mathrm{A}$ & $\mathrm{B}$ & $\mathrm{C}$ & $\mathrm{A}$ & $\mathrm{B}$ & $\mathrm{C}$ & $\mathrm{A}$ & $\mathrm{B}$ & $\mathrm{C}$ \\
\hline 1 & 6.42 & 6.56 & 5.54 & 6.69 & 6.27 & 4.90 & 6.45 & 6.75 & 5.44 \\
\hline 2 & 8.49 & 7.50 & 5.42 & 5.34 & 4.86 & 3.13 & 11.74 & 9.87 & 6.64 \\
\hline 3 & 15.72 & 15.04 & 11.19 & 4.97 & 4.90 & 3.87 & 7.81 & 7.18 & 5.08 \\
\hline 4 & 11.82 & 11.32 & 8.87 & 5.11 & 5.09 & 4.17 & 6.77 & 6.56 & 4.75 \\
\hline 5 & 8.31 & 8.28 & 7.48 & 7.46 & 7.50 & 7.16 & 8.48 & 8.58 & 8.14 \\
\hline 6 & 9.08 & 8.95 & 8.05 & 7.63 & 7.67 & 7.12 & 6.87 & 6.88 & 6.53 \\
\hline 7 & 9.05 & 9.15 & 8.09 & 7.76 & 7.87 & 7.42 & 7.50 & 7.54 & 7.07 \\
\hline 8 & 6.76 & 6.24 & 5.56 & 8.13 & 6.90 & 5.77 & 5.82 & 5.52 & 4.87 \\
\hline
\end{tabular}

3

4 


\section{Figure captions}

2 Figure 1. The modeling domain. The coastline data were obtained from National Geophysical

3 Data Center and has a resolution of 1:250,000. The digital elevation model data are shown at a

$41000 \mathrm{~m}$ interval and are derived from the USGS GTOPO30 dataset which has a grid spacing of

530 arc seconds. The model receptors are shown by the dots and the air quality monitoing stations

6 are shown by the triangles. The international border is shown by the solid black line.

\begin{tabular}{|c|c|}
\hline Site & Location \\
\hline Slocan Park (within the city of Vancouver) & $49^{\circ} 14^{\prime} 38^{\prime} \mathrm{N}^{\circ} 123^{\circ} 02^{\prime} 55^{\prime \prime} \mathrm{W}$ \\
\hline $\begin{array}{c}\text { Langley (south of the city of Vancouver in a } \\
\text { relatively rural/sub-urban context) }\end{array}$ & $49^{\circ} 01^{\prime} 42^{\prime \prime} \mathrm{N}, 122^{\circ} 36^{\prime} 13^{\prime \prime} \mathrm{W}$ \\
\hline $\begin{array}{c}\text { Chilliwack (approximately 60 km east of } \\
\text { Vancouver) }\end{array}$ & $49^{\circ} 07^{\prime} 35^{\prime \prime} \mathrm{N}, 121^{\circ} 56^{\prime} 15^{\prime \prime} \mathrm{W}$ \\
\hline
\end{tabular}

7

8 Figure 2. Back-trajectories computed for the Langley receptor location for each episode (shown

9 by the start date of the three day episode). Frame (a) shows the trajectories for simulation

10 number 1, (b) for simulation number 2, and so forth. The simulation periods are shown below:

\begin{tabular}{|c|c|c|}
\hline Simulation \# & $\begin{array}{l}\text { Start (year-month-day hour of } \\
\text { the day) }\end{array}$ & $\begin{array}{l}\text { End (year-month-day hour of } \\
\text { the day) }\end{array}$ \\
\hline \multicolumn{3}{|c|}{ Winter periods (DJF) } \\
\hline 1 & $2003-12-220900$ & $2003-12-242200$ \\
\hline 2 & $2004-2-120900$ & $2004-2-142200$ \\
\hline \multicolumn{3}{|c|}{ Spring periods (MAM) } \\
\hline 3 & 2004-4-100900 & 2004-4-12 2200 \\
\hline 4 & 2004-4-300900 & $2004-5-22200$ \\
\hline \multicolumn{3}{|c|}{ Summer periods (JJA) } \\
\hline 5 & $2004-6-200900$ & $2004-6-222200$ \\
\hline 6 & 2004-7-210900 & $2004-7-232200$ \\
\hline 7 & 2004-8-90900 & $2004-8-112200$ \\
\hline \multicolumn{3}{|c|}{ Fall periods (SON) } \\
\hline 8 & 2004-10-30900 & $2004-10-52200$ \\
\hline
\end{tabular}

11

12 Figure 3. Inorganic aerosol components (in $\mathrm{nmol} \mathrm{m}^{-3}$ ) for the three sets of experiments shown by

13 the simulation number (note only every second simulation number is explicitly labeled on the $\mathrm{x}$ - 
1 axis $(1,3,5,7))$. For the sea-spray sulfate, concentrations are given as excess above primary sea-

2 spray emissions. The vertical scale differs with frame. Here (a) Slocan Park, (b) Langley and (c) Chilliwack.

4

5 Figure 4. Light extinction calculated using the simulated particle concentrations and the IMPROVE protocols for experiments A and B for (a) Slocan Park, (b) Langley and (c) Chilliwack.

9 Figure 5. Mean gas concentrations for the experiment B simulations (shown by simulation 10 number) at (a) Slocan Park, (b) Langley and (c) Chilliwack. NB. For ozone concentrations the 11 maximum hourly concentrations are given while for the other gases the mean concentrations are shown. 


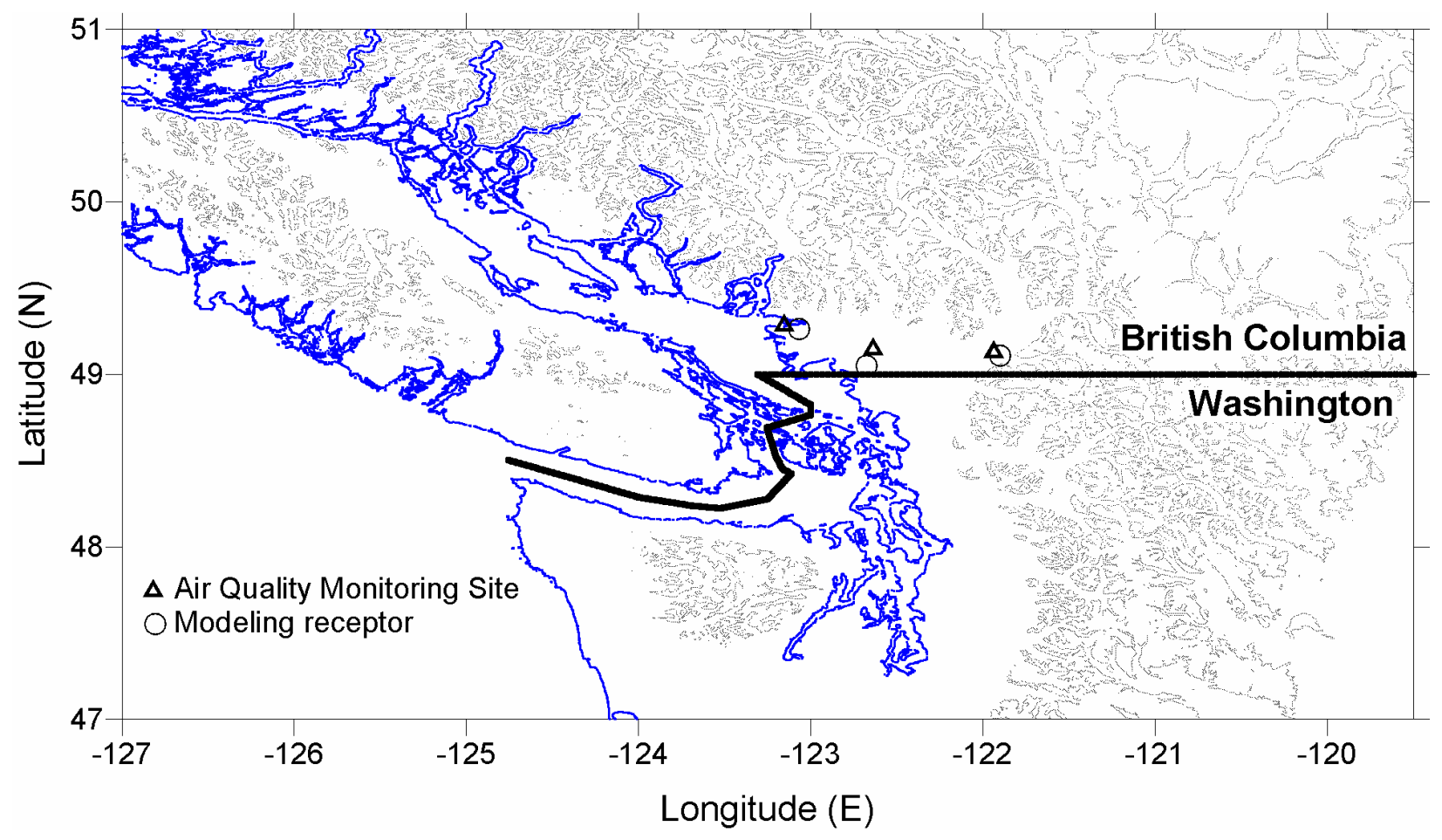

Fig 1. 

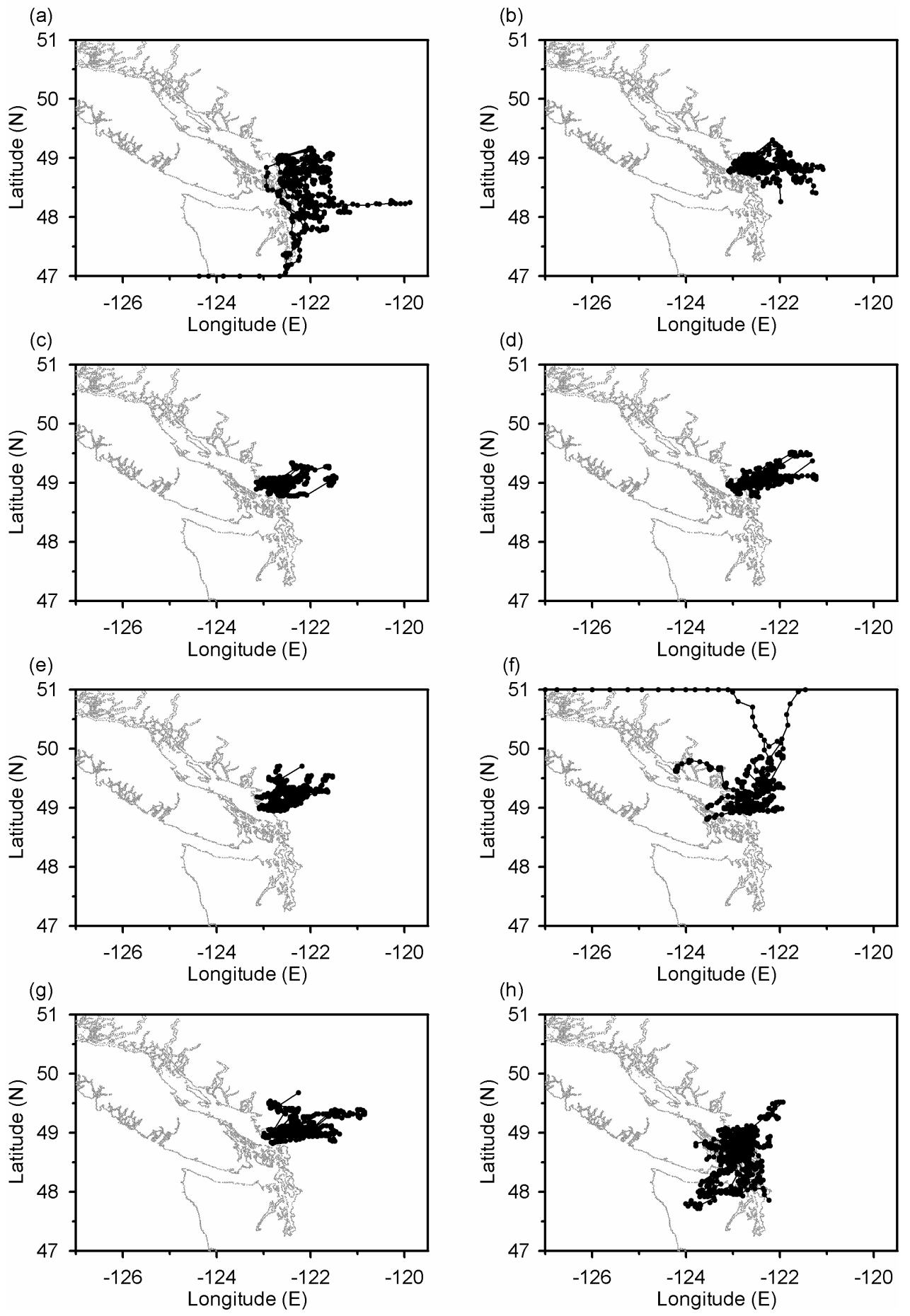

Fig 2. 


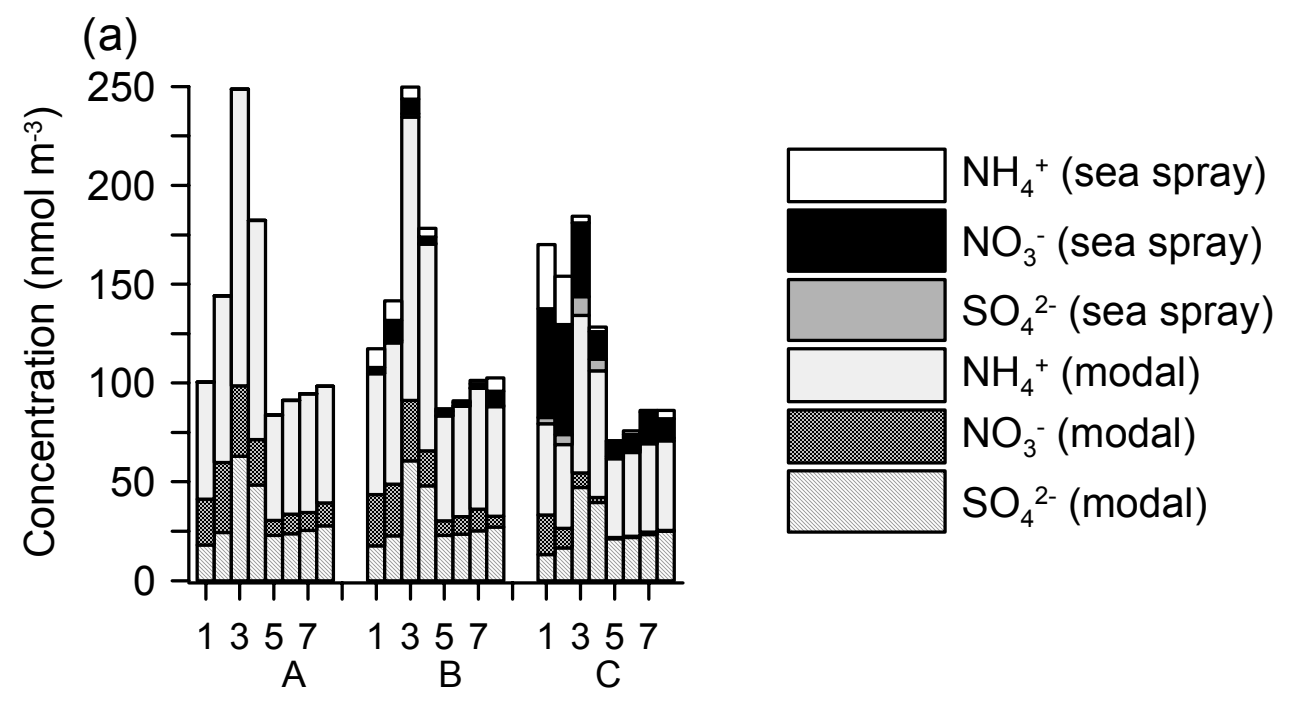

(b)

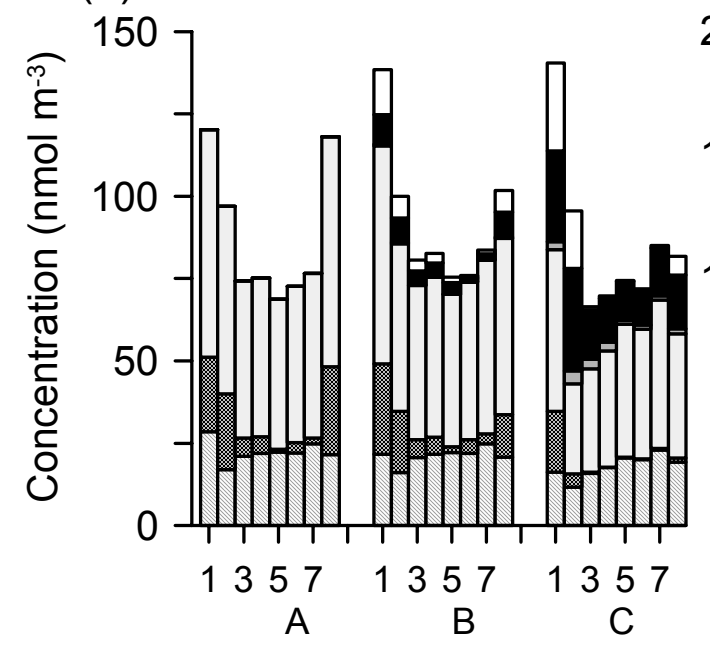

(c)

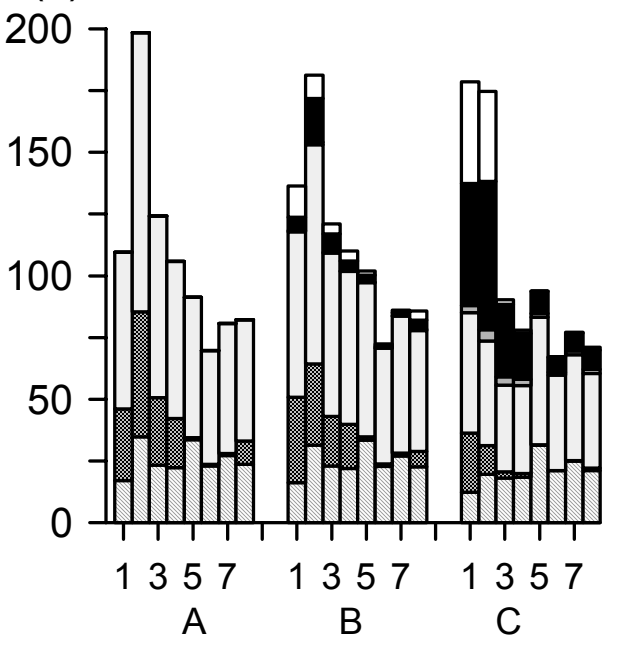

Fig 3.

3 


\section{(a)}
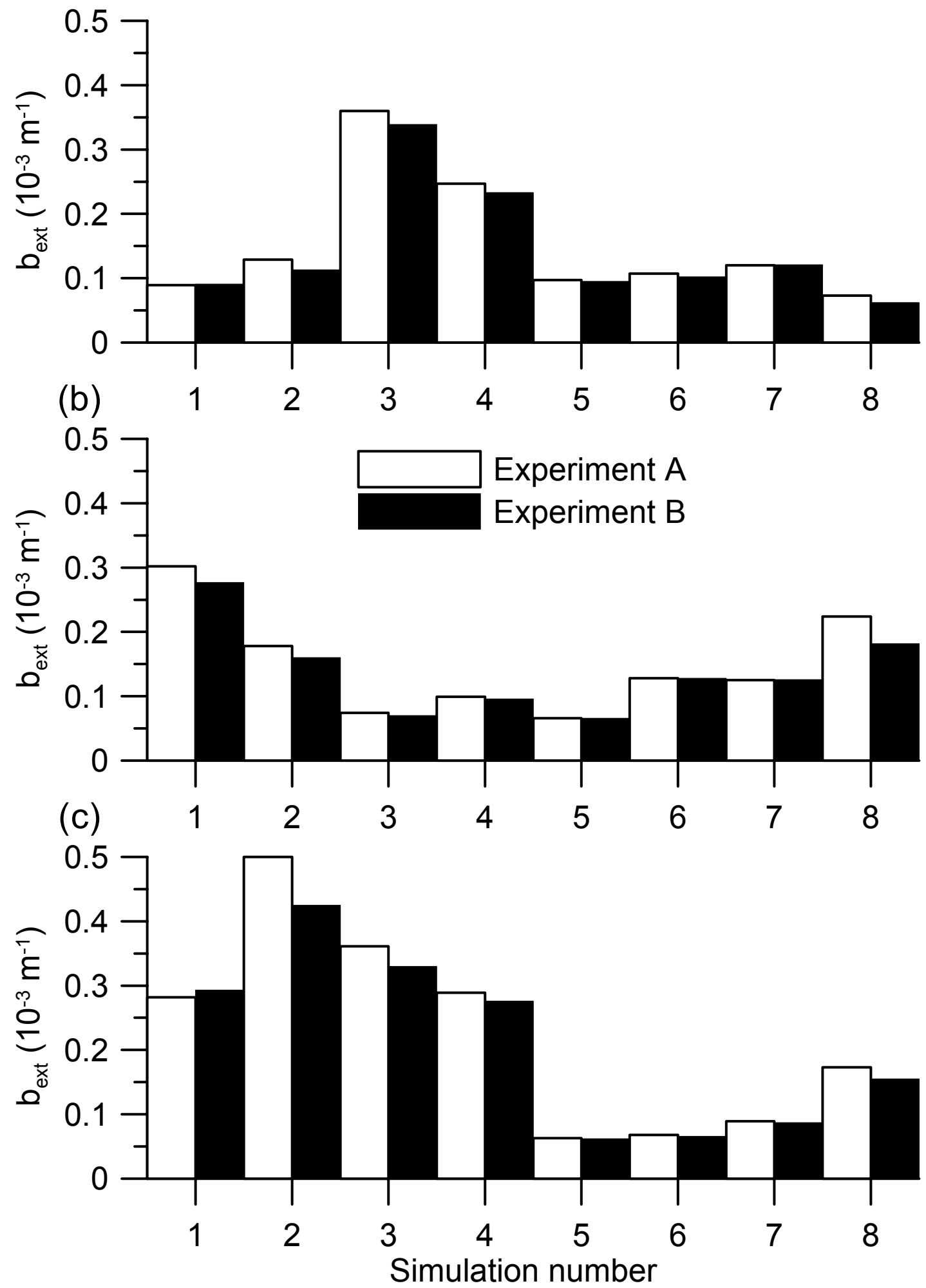

Fig. 4. 


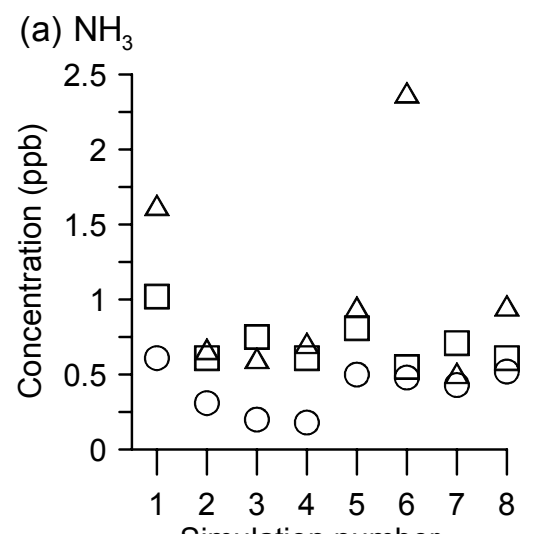

(c) $\mathrm{HNO}_{3}$

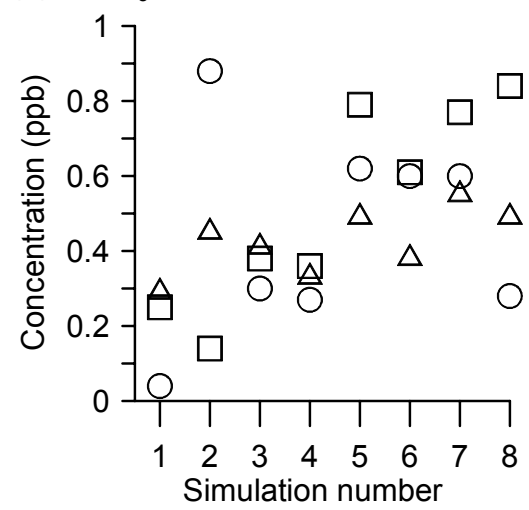

Simulation number

\begin{tabular}{|c|l|}
\hline \multicolumn{1}{|c|}{ Modeled } \\
$\triangle$ & Slocan Park \\
$\square$ & Langley \\
$\bigcirc$ & Chilliwack \\
\hline
\end{tabular}

(b) $\mathrm{SO}_{2}$

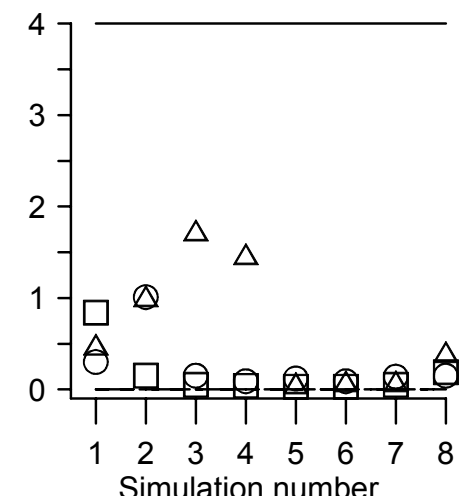

(d) $\mathrm{O}_{3}$

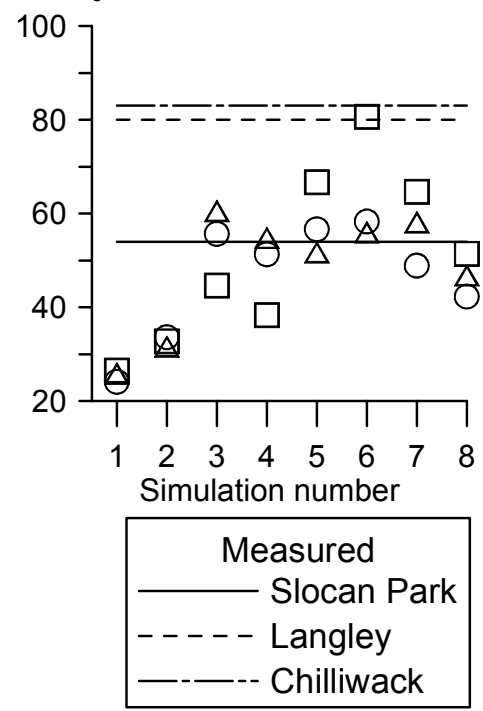

Fig 5. 